\title{
Online Oral Negotiated Interaction: A Study of Brazilian Beginners Using WhatApp
}

\section{Nayara Salbego ${ }^{1 *} \&$ Celso Tumolo ${ }^{2}$}

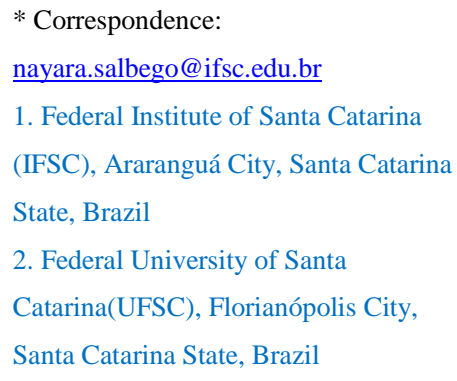

* Correspondence:

nayara.salbego@ifsc.edu.br

1. Federal Institute of Santa Catarina

(IFSC), Araranguá City, Santa Catarina

State, Brazil

2. Federal University of Santa

Catarina(UFSC), Florianópolis City,

Santa Catarina State, Brazil

Received: 18 April 2020

Revision: 1 June 2020

Accepted: 6 July 2020

Published online: 20 September 2020

\begin{abstract}
This article reports on a study of interaction amid beginners with the use of the technological resource WhatsApp. Its major objective was to analyze online oral negotiated interaction characteristics, using mainly WhatsApp audio-recorded messages, but also multimodal interaction (text, images, GIFs, emoticons, etc.). It was a qualitative, interpretive, and exploratory case study applied to 33 participants from a public technical school in Brazil, in which participants were in the first year of High School. The analysis revealed that negotiated interaction was the main component of interaction, although in a different sense if related to the theoretical framework held in Second Language Acquisition (SLA). Therefore, this study added a discussion on interaction in SLA, which considered the peculiarities of the online oral negotiated interaction among beginner learners of English using WhatsApp. The interpretive findings discussed in this article may enlighten pedagogical practices in SLA as well as broaden possibilities in terms of activities development to work on online oral interaction amongst beginners, with the aid of technological resources. Finally, this study may serve the purpose of promoting reflections on SLA theories about interaction.
\end{abstract}

Keywords: Brazil EFL, English beginners, $\underline{\text { meaning negotiation, online oral }}$ negotiated interaction, WhatsApp EFL interaction, WhatsApp audio$\underline{\text { recorded messages }}$ 


\section{Introduction}

Interaction through technological resources represents a way of supporting learners with broader opportunities to practice the target language (Thomas, Reinders, \& Warschauer, 2014), especially in an English as a foreign language (EFL) context, such as Brazil. However, interacting online may differ from the traditional face-to-face encounter (Hampel \& Stickler, 2012; Jones, Murphy, \& Holland, 2015; Verjano, 2013; Yanguas, 2010). In addition to that, it is also essential to consider that the affordances of each technological resource (e.g. Skype, WhatsApp, Facebook, Google Hangouts) may play a role on the interaction characteristics.

Communication through oral interaction is inherent to social relations. In this sense, people learn languages to interact with others and the world itself, which would make oral interaction, again through language, a key to live in this world. In agreement with the need for oral interaction, this study added a technological resource to go hand in hand with that, consequently having online oral interaction as its paramount focus of analysis. Additionally, the current situation of English language teaching and learning in most contexts of the Brazilian educational scenario is in need of having more oral interaction development for our learners. To illustrate that, we can think of the national parameters that guide the teaching of languages in Brazil (PCNs, 2000), in which the reading skills gained more emphasis if compared to the other skills - speaking, listening and writing. However, we took into consideration that Second Language Acquisition (SLA) has long stated that oral interaction is essential for language learning. Therefore, this study aimed at addressing that need by analyzing ways possible to promote more oral interaction opportunities for our learners.

Furthermore, some Brazilian scholars, such as Cunha (2016), Lima (2009, 2014), Miccoli and Cunha (2016), and Oliveira (2014) hold that the prevailing characteristics of English language teaching in Brazilian regular schools have long been: (a) teacher-centered classes held in Portuguese; (b) grammar rules memorization as the major approach; (c) learners allowed few or, most of all, no opportunities for speaking or interacting orally in English; and (d) the speaking and listening skills are mostly left aside. Because of that, the results of this study may contribute to reflections in the sense of promoting oral interaction for our learners with the aid of technological resources, such as the app WhatsApp.

In consideration of the above mentioned, this study aimed to point to a perspective into English pedagogy through the unveiling of online oral interaction characteristics, using WhatsApp. By working with an app that is already typical among learners in Brazil, teachers may foster students' abilities with online interaction, granting opportunities for the target language development.

\subsection{Statement of the Problem and Theoretical Support}

In Brazil, most English teaching and learning tend to focus on reading and grammar (Cunha, 2016; Lima, 2009, 2014; Micolli \& Cunha, 2016; Oliveira, 2014). However, research results advocate that for learning a language to communicate, it is essential to develop the basic four skills - reading, writing, listening, and speaking (Menezes, 2010, 2013, 2018). In this sense, this investigation focused on trying to unveil possibilities of working on the speaking and listening skills of beginner learners of English.

For that reason, the theoretical framework that grounded this study was mainly based on SLA theories on interaction (Compernolle, 2015; Ellis, 1991, 1999; Long, 1981, 1996; among others), particularly concerning negotiation of meaning (Jungmi, 2003; Smith, 2003; Varonis \& Gass, 1985). In addition, this study looked at interaction characteristics from a socio-interactionist point of view (Chapelle, 2003; Compernolle, 2015; Ellis, 1999), in which a holistic perspective of the interactional context was taken into account for the interpretation and analysis of the data collected.

In the same line, considerations from Computer-Assisted Language Learning (CALL) studies carried out worldwide were also enlightening the understanding of technological resources role for language learning, especially regarding online interaction (Blake, 2005, 2008; Bower \& Kawaguchi, 2011; Fernández-García \& Martínez-Arbelaiz, 2002; Hampel, 2012; Kenning, 2010; Kern, 1995; Smith, 2003; Stickler, 2016; Verjano, 2013; Warschauer, 1996; Yanguas, 2010; among others). In the Brazilian context, some studies were indeed insightful for this research. As examples, we found studies related to the use of WhatsApp for general pedagogical purposes (Oliveira et al., 2014; Rodrigues, 2016), for language learning purposes (Castrillo et al., 2014; Castrillo et al., 2015; Severo, 2017) and the analysis of WhatsApp chat as a genre also related to language learning (Leite \& Silva, 2015). 
The app WhatsApp was selected due to its popularity among language learners and researchers in the Brazilian context and worldwide (Amry, 2014; Bouhnik \& Deshen, 2014; Castrillo, Martín-Monje, Bárcena, 2014, 2015; Kaieski, Grings, \& Fetter, 2015; Leite \& Silva, 2015; Plana, Gimeno, Appel \& Figueras, 2013; Rambe \& Bere, 2013; Souza, 2015). Added to that, the easy and free access make this app a ubiquitous resource in learners' lives, especially regarding the participants of this study. Most especially, it was selected for this study because learners can use it to practice the target language orally by voice chat, also in the form of audio-recorded messages. Indeed, the voice chat was the main source of data collection in this investigation.

\subsection{Research Questions}

Bearing that in mind, this study examines elements that describe characteristics of online oral interaction among beginner learners of English, specifically using the app WhatsApp. To pursue the goals of this study, the following research questions were formulated:

a. What are some characteristics of online oral audio-recorded negotiated interaction among beginner learners of English, considering the affordances of WhatsApp?

b. How did the affordances of the app WhatsApp play a role in the negotiated interaction characteristics of beginner learners of English, considering existing negotiation of meaning models?

c. Which communication resources - multimodal (textual, visual, \& aural) - were used by the participants to assist their oral interaction online on WhatsApp and how they may have interplayed with the interaction?

In consideration of the aforementioned, the results of this study may point to different perspectives into English pedagogy through the unveiling of online oral interaction characteristics, using the app WhatsApp among beginner learners of English. By working with an app that is already familiar among learners in Brazil, teachers may foster students' abilities with online interaction, providing opportunities for the target language development.

\section{Review of the Literature}

\subsection{Interaction in SLA}

In SLA, interaction has been seen as fundamental for L2 learning. In fact, research has demonstrated that language development may result from interaction. In this regard, Long (1981) proposed the Interaction Hypothesis after analyzing native-speakers (henceforth NS) interacting orally with native and non-native speakers (henceforth NNS) of multiple languages in his doctoral dissertation. The author investigated how oral interaction happened and how it could benefit language learning.

Hatch (1978) has also been recognized as one of the pioneers investigating interaction for language learning. The author holds that interaction may lead to development in language learning. To support that, the author investigated first language learning amidst children and confirmed her claim. For Hatch, interaction was used as a synonym for conversation, meaning verbal oral interaction, that is, people talking to each other. In addition, a language learner uses resources similar to the ones children use when interacting orally. For instance, repetition, repair, rephrasing, clarification, comprehension requests, and confirmation checks are among them, named 'interactional adjustments' by Long (1981). Hatch (1978) concluded that more research in the area was necessary for further understanding how interaction happens in language learning in particular.

Based on the aforementioned assertions, Long (1981) further investigated Hatch's (1978) proposal. In his doctoral dissertation, the author pointed out that negotiation of meaning was a key element that interaction entails (Mitchell \& Myles, 2004). In another publication that furthers the discussion on the topic, Long (1996) defined that:

$[\mathrm{N}]$ egotiation for meaning, especially negotiation work that triggers interactional adjustments by the NS or more competent interlocutor, facilitates acquisition because it connects input, internal learner capacities, particularly selective attention, and output in productive ways. (p. 451-452)

To state the assumptions of the Interaction Hypothesis, Long investigated two different dyads interacting: NSs $x$ NSs and NSs $x$ NNSs. As a result, the author identified that the pairs NSs $x$ NNSs negotiated more meanings through interactional adjustments, such as repetitions, confirmation checks, repairs, comprehension requests, and clarifying requests. In this sense, interactional adjustments refer to resources used to indicate that interactants are trying to communicate and understand each other by negotiating meanings. In fact, Long (1996) developed his rationale on his 
initial proposal and stated that negotiation of meaning happens through interaction in a way that interactants may notice problems in their communication, which allows for an allusion to the Noticing Hypothesis by Schmidt (1990). The author claimed that noticing may help learners to enhance learning or correct what they already know. In addition, the author emphasized that, in a language classroom context, interaction should be fostered through designed activities that stimulate interaction through negotiation of meaning.

Long (1996) identified that there are more modifications in the language produced as output than in the input of NSs. In other words, just by receiving input learners may develop their language skills, but trying to produce language through interaction may be more beneficial. For the author, input is necessary, but it is interaction and the use of input that is paramount for language learning. Therefore, this assumption allows an allusion to the Output Hypothesis (Swain, 1985, 1995) and, in this sense, negotiation of meaning represents the core of interactional adjustments.

\subsection{Interaction through Negotiation of Meaning}

Interaction can be beneficial for language learning since it entails negotiation of meaning. Long (1981) supported that it is interaction that has the potential to foster language learning. Long (1996) defined it as:

[T] he process in which, in an effort to communicate, learners and competent speakers provide and interpret signals of their own and their interlocutor's perceived comprehension, thus provoking adjustments to linguistic form, conversational structure, message content, or all three, until an acceptable level of understanding is achieved. (p. 448)

For Long (1996), negotiation of meaning includes adjustments by the interactants to understand each other and to make themselves comprehended by their interlocutors. These adjustments could be in terms of linguistic form, conversational structure, message content, or all three together. Negotiation of meaning may result in negotiated interaction (Long, 1981, 1996), which means that the interactants made adjustments to linguistic form, conversational structure, message content, or all three, in order to understand their interlocutors or to be understood. As research on the topic developed, scholars explained that these adjustments resulted from language breakdowns, referring to language non-understandings that need to be solved for the interaction to continue (Bower \& Kawaguchi, 2011; Ellis, 1999; Foster \& Ohta, 2005; Gass \& Selinker, 1994; Long, 1996; Mackey, 2007; Mackey et al., 2000).

Long (1996) claims that negotiation of meaning is triggered when a breakdown in communication occurs in conversation, leading to a modified utterance either from the L2 learner or their interlocutor. The author describes negotiation of meaning as a "communicative trouble" that "can lead learners to recognize that a linguistic problem exists, switch their attentional focus from message to form, identify the problem and notice the needed item in the input" (Long, 1996, p. 425). In these negotiations, problem utterances are checked, repeated, clarified, or modified in some way (lexically, phonologically, morpho-syntactically). These negotiations provide learners with negative evidence about their own output, and push them to modify it to make it more comprehensible and more target-like (Swain, 1985).

Most negotiation routines identified in research are lexical (Bower \& Kawaguchi, 2011; Shekary \& Tahirian, 2006; Yanguas, 2010), that is, usually an unknown term appears and the flow of interaction is paused to resolve it as a language breakdown. Moreover, Jungmi (2003) claims that in NNS x NNS interaction, a participant who has an ability to control, initiate, and end negotiation of meaning is more involved in the conversation by trying to make it move smoothly and in a mutually comprehensible way.

In line with that, Ellis (1991, p. 37) stated that learner production resulting from the "attempt to negotiate meaning can facilitate the process of integrating new features into their interlanguage." Recognizing the importance of noticing and comparisons in negotiated interactions for acquisition, the author claimed that learners compare what they know or do not know while receiving modified input resulted from negotiated interaction.

During the initial discussions on negotiation of meaning in interaction, Varonis and Gass (1985) developed a model to describe the phenomenon. They defined that there are two main phases in the model: the Trigger and the Resolution phases. In the Trigger phase, there is the presentation of the problem, which is represented by the language breakdown, also known as language misunderstanding (Ellis, 1991). Then, a signal by the hearer is provided, which may be a sound or sentence signalling the incomprehension. With that, it is possible to identify the need for negotiation of meaning being indicated by one of the interactants. That explains why the authors also name this phase as Indicator. In the sequence, the Resolution phase comes after the Trigger or Indicator phase to convey the resolution to the communication problem, which is resolved with the Response by the speaker and the Reaction by the hearer. 
Smith (2003) expanded Varonis and Gass' (1985) model by adding two other phases: the Split negotiation routine and the Reconfirmation phase. In the Split negotiation routines, learners continue the conversation without providing clues or even resolving the communication non-understandings that require meaning negotiation. However, they may come back to that later during the interaction. This would characterize a Split negotiation routine, which is 'split' because it happens in parts, instead of an uninterrupted continuum. Additionally, the Reconfirmation phase happens when a response by the speaker is reconfirmed to assure understanding.

Following the same rationale of Smith's (2003), Jungmi (2003) carried out a study on online interaction based on Varonis and Gass' (1985) model for negotiation of meaning. The author proposed two main additional phases: the Pushdown and Pop phases. The Pushdown phase refers to when the negotiation of meaning starts happening, that is, the horizontal flow of the conversation is pushed down. The other addition to the model, the Pop phase, describes the situation when the interaction returns to a normal state, that is, a state without interruptions. That happens when interactants continue discussing the topic that they were talking about before the pushdown came to the fore. Jungmi (2003) explains that, while Varonis and Gass' (1985) Negotiation of Meaning Model has two main phases, the Trigger and the Resolution, the model proposed by Jungmi (2003) has five phases: Pushdown, Feedback, Reaction, Reinforcement, and Pop. Some of these phases can be compared to Varonis and Gass' (1985) model; however, Jungmi renamed them to address the specificities attributed to the terms used.

As for this study, a combination of the models presented is used (Jungmi, 2003; Smith, 2003; Varonis \& Gass, 1985) in order to have a more thorough analysis of the online oral interaction characteristics among beginners, with the use of the app WhatsApp. Besides that, this study considers that a combination of models may fit more appropriately its characteristics because the phases firstly proposed by Varonis and Gass (1985) may not be able to account for the holistic characteristics of online interaction. Thus, the combination uses Varonis and Gass' as well as Smith's and Jungmi's models.

\subsection{Interaction on WhatsApp}

Considering research that involved WhatsApp for general educational perspectives, a bibliographical study by Rodrigues (2016) presents a review from 2013 to 2016 concerning topics that have been studied using the application WhatsApp for pedagogical purposes in different areas of knowledge, specifically in the Brazilian context. The author presents article titles and a brief comment on each one of them. The results point to both negative and positive aspects in relation to the use of WhatsApp for pedagogical reasons. Some of the studies (Rodrigues, 2016) presented are discussed in this section, added to other relevant investigation that are connected to the objective of this article.

Oliveira et al. (2014) presented positive results from a study that aimed to analyze the use of WhatsApp as a formal environment for language learning. The authors highlighted the development of learner autonomy since the participants could decide when, where, and how to act in the learning environment, not necessarily being at the educational context at the time. Additionally, other advantages found in the study were related to portability and mobility since the participants had easy access to the WhatsApp group to carry out the proposed activities or participate in the group discussions.

Concerning the more specific objectives related to online interaction to language learning, Castrillo et al. (2014) analyzed online written interaction through WhatsApp. More specifically, the authors investigated negotiation of meaning among beginner learners of German who were Spanish native speakers. Based on previous studies, the authors identified three main discourse functions that were: a) social interaction (greetings and farewells); b) on-task negotiating meaning; and c) off-task conversations. In each type of discourse functions, the authors analyzed negotiation of meaning, emphasizing error correction and feedback (clarification requests, confirmation, and repetition). Among the main findings, they showed that students improved their meaning negotiation skills and reduced the number of mistakes (lexical, morphological, and syntactic). Also, they described the activity as suitable for beginners and they indicated that it represented a way of substituting the usual error correction and feedback provided by the teacher to more subtle forms of eliciting students' awareness.

Also referring to language learning, Severo (2017) analyzed how the process of learning was mediated as students chatted on the app WhatsApp as part of their class activities. The author analyzed students' production on the chat application, focusing on how they scaffolded each other, noticed gaps (Swain, 1985, 1995), and negotiated meaning (Long, 1981), while interacting online for learning English. The author found that the app WhatsApp could be an 
effective resource to engage students in producing language since students tested hypothesis, noticed gaps in their knowledge and resorted to metatalk to interact.

Still regarding language learning, there have been other studies dedicated to the understanding of potential uses of WhatsApp for pedagogical purposes (Aragão, 2017; Aragão \& Lemos, 2017; Fonte \& Caiado, 2014; Susilo, 2014). Aragão (2017) and Aragão and Lemos (2017) studied teachers' perceptions on the use of WhatsApp for oral interaction in English. The results pointed to the fact that participants were more willing to interact through the app than F2F, except when they had to record their voices for feeling more insecure.

Fonte and Caiado (2014) and Susilo (2014) analyzed communication on the app seen as discourse. They looked at aspects such as visual and textual elements, specially concerning how the use of WhatsApp may benefit language learning. While Fonte and Caiado (2015) centered their study specifically on multimodal discursive practices used in WhatsApp communication, Susilo (2016) focused on students' discursive participation through virtual ethnography. Results from both studies showed the positive impact of multiple semiotic resources available for constructing meaning in the online interaction through WhatsApp.

Furthermore, there have been authors who elucidated proposals of pedagogical activities using the app WhatsApp (Salbego \& Tumolo, 2018; Senefonte \& Talavera, 2018). Salbego and Tumolo (2018) described one activity and emphasized the importance and need of working on oral skills through interaction in the context of the Brazilian educational system. Senefonte and Talavera (2018) proposed a series of activities regarding the four skills: listening, speaking, reading, and writing. The authors (Salbego \& Tumolo, 2018; Senefonte \& Talavera, 2018) also described ideas on how to use WhatsApp for developing visual literacy and working on text messaging skills. Both studies can be relevant to have more hands-on ideas concerning the use of an app for teaching and learning languages.

In summary, the studies presented analyzed the use of WhatsApp for general pedagogical purposes (Oliveira et al., 2014; Rodrigues, 2016) and for language learning purposes (Castrillo et al., 2014; Castrillo et al., 2015; Severo, 2017). The studies emphasized characteristics such as the development of autonomy and negotiation skills for interaction analyzed in their participants' use of the app for language learning. In the same way, they highlighted the engagement of the participants in producing language, which was verified by tested hypotheses, noticed gaps and use of metatalk to interact. In addition, participants were more willing to interact through the app than F2F (Aragão, 2017; Aragão \& Lemos, 2017) and they used multiple semiotic resources available for constructing meaning (Fonte \& Caiado, 2014; Susilo, 2014).

Finally, the theoretical discussions promoted by the authors, the study objectives, and the results presented in this section guided paths in this investigation, besides adding hands-on ideas concerning the use of the app (Salbego \& Tumolo, 2018; Senefonte \& Talavera, 2018). Indeed, the reflections on this section helped to look at the data collected with broadened views in what regards the use of the app for learning, mainly language learning.

\section{Methodology}

\subsection{Design of the Study}

Data were examined qualitatively (Cohen, Manion, \& Morrison, 2011; Dörnyei, 2011; Firestone, 1987; Griffee, 2012; Nunan, 2008; Strauss \& Corbin, 1998). This study was exploratory since it took into consideration online interaction among beginner learners of English, whilst most studies found so far analyzed intermediate and advanced learners (Hampel \& Stickler, 2012; Jepson, 2005; Kenning, 2010). Additionally, it included non-native speakers learning English as a foreign language. The majority of the studies identified so far have investigated non-native speakers interacting in English as a second language (Hampel \& Stickler, 2012; Heins et al., 2007; Jones, Murphy, \& Holland, 2015; Yanguas, 2010). Additionally, studies have analyzed speakers of English as their native language interacting with speakers of other languages (e.g. German, Spanish) (Guo, 2013; Tudini, 2003; Verjano, 2013) and interaction among speakers of English as a second language (Amry, 2014; Bouhnik \& Deshen, 2014; Kaieski, Grings, \& Fetter, 2015; Rambe \& Bere, 2013). Instead, this study analyzed interaction among non-native speakers who use English as a foreign language. Moreover, it was an inductive research (Griffee, 2012; Nunan, 2008) in which the criteria and categories for data analysis emerged from the data collected.

Still concerning the method of analysis and study design, this research can also be characterized as a case study (Cohen, Manion, \& Morrison, 2011; Dörnyei, 2011; Griffee, 2012; Nunan, 2008) in which a specific group of people was analyzed, considering their sociocultural context of interaction (Compernolle, 2015). It was a systematic analysis 
that examined the phenomena of online oral interaction in its natural setting, according to the WhatsApp activity proposed. Following Griffee's (2012) discussion on the delineation of what composes a case study, this research sought to create a deep explanation of the data based on the analysis carried out.

\subsection{Participants and Setting}

The participants of the study were 33 first-year high schoolers from a public technical school, located in the south of Brazil. Their ages ranged from 14 to 17 years old. Their English learning experience happened in the mandatory curriculum of basic education, in the Brazilian educational system. As their statements in the profile questionnaire presented, their English learning experience was mainly based on grammar topics memorization, which is a characteristic of the subject English as a Foreign Language in most regular schools in Brazil (Cunha, 2016; Lima, 2009; Lima, 2014; Miccoli \& Cunha, 2016; Oliveira, 2014). According to the participants' views, they had had mostly grammar, vocabulary and reading instruction. In order to determine the participants as beginners in English, a proficiency test (TOEIC Bridge-Test of English for International Communication) was applied. Afterwards, participants provided the teacher-researcher with their TOEIC scores. According to the results, the participants' average score of 49 in each skill, be they reading and listening, can be classified between the A1 and A2 levels, following The Common European Framework of Reference (2001) and Tannenbaum and Wylie (2015). Therefore, the results indicated that they were basic users of English.

\subsection{Instruments}

The data collection in this study required a mobile device in which participants had previously installed the app WhatsApp. In addition, the investigation also made use of Google Forms for the questionnaires used. Firstly, participants responded to a personal information questionnaire online on Google Forms. This instrument elucidated aspects related to who the participants were, the sort of experience they had had with English prior to this research, and their perceptions regarding their levels of English considering different skills - reading, writing, listening, speaking, grammar, and vocabulary.

Secondly, participants did an activity on WhatsApp. They were instructed to interact orally online by recording messages to each other. However, they were also encouraged to write messages or use emoticons, images, short videos, GIFs, or any type of online communication that could help them to negotiate meaning with one another to accomplish the objective of the activity proposed (further explained in section 3.3.1 WhatsApp Activity for Online Oral Interaction). Bearing that in mind, the main objective of this study was to analyze characteristics of online oral audiorecorded negotiated interaction among beginner learners of English, considering which and how communication resources - multimodal (textual, visual, aural) - were used to assist their oral interaction online on WhatsApp.

\subsubsection{WhatsApp Activity for Online Oral Interaction}

The type of activity proposed for this study is popularly called 'spot-the-differences.' The objective was to promote oral interaction in English by using WhatsApp with their pairs or trios, by recording audio messages, to describe and find at least 8 differences, although the images used had about 12 differences. The time to carry out the activity was limited to 30 minutes; this time was set based on Yanguas (2010) and on the pilot study carried out for this investigation. The activity could be described as an information-gap and/or jigsaw task. In the former, each of the interactants had part of the answers and they needed to share information and negotiate meanings to accomplish the final objective of the activity. In the latter, each interactant held a different piece of information and supplied or requested this information as needed to complete the task.

\subsection{Procedures for Data Collection}

Participants formed pairs or trios. Then, they created a WhatsApp group on the app. After that, they added the teacherresearcher, so that access to the audio files and other multimodal communication was facilitated. Before they started interacting, participants were separated into two rooms or different physical locations with the aim of putting pairs and trios members away from each other. Following the initial instructions, the pairs and trios could choose other places to go to, inside the school campus, to be physically separated or away from one another. After about 5 minutes of the beginning of the activity, participants were free to wander on campus, where the teacher-researcher could see them, as long as they did not stand close to their pair or trio partners. The objective was to maintain students belonging to the same pair or trio in different physical spaces in order to have a reason to interact online instead of F2F. Other 
than that, since they were mostly recording voice messages, the sounds of their voices could not disturb each other. Consequently, the physical distance was essential for the data collection and main objective of the study.

\subsection{Procedures for Data Analysis}

The teacher-researcher transcribed the oral interaction from the app WhatsApp, separating them per dyads or triads, and then saving them into computer audio files. A print screen of each WhatsApp group interaction was registered, showing each recorded audio, its time and duration, as well as the multimodal interaction (textual, visual, \& aural). The print screen images were saved as images. Along with the audio files, the teacher-researcher had to check all the print screen images in order to check which messages were quoted and, mainly, to check if multimodal means of communication (textual, visual, \& aural) were used during the interactions.

The data analysis was interpretive and descriptive (Matos, 2011). The teacher-researcher selected excerpts based on how they illustrated the main characteristics found in all the dyads and triads WhatsApp interaction. Effectively, the excerpts were transcribed and then interpreted, following the characteristics identified, which were determined based on the frequency and relevance of their occurrences among all the dyads and triads. As a result, the most recurring characteristics were selected based on their frequent occurrence or meaningfulness in the online oral interaction among participants. To illustrate, examples from the transcripts were selected to be included in the analysis section as excerpts from each interaction, according to the characteristics identified.

\section{Findings}

\subsection{Characteristics of Online Oral Interaction among Beginners on WhatsApp}

For the data collection activity, participants were asked to describe images to their peer(s) with the objective of spotting at least 8 differences within 30 minutes. Participants formed pairs or trios in which the members were spatial and physically separated to interact through the app WhatsApp. Such activity was originally proposed in the textbook New Cutting Edge, Starter level. However, it was not originally aimed at being carried out with the aid of a technological device; it was considered as a speaking task in the textbook (Cunningham \& Moor, 2014). Nonetheless, this study adapted it to its objectives based on theoretical groundings that identified benefits in terms of language learning with different learning technologies (Thomas et al., 2014). To delineate specific aspects of the interaction features, excerpts of interaction were presented in tables that show the number of the line that corresponds to each turn taken by the participants in their pairs or trios. In addition, we added the fictional names of whom was taking the turn. We also indicate the turn time and duration. The most important part in the transcriptions, the turn talk, shows the utterances in each turn of the participants. Finally, we pointed out if the content of each turn was characterized as negotiated interaction, using 'Yes', or not, being identified by 'No' in the final column of each table.

\subsubsection{Negotiated Interaction}

Excerpt 1, participants were talking about the location of flowers in each of their images; they were negotiating meaning about the word 'bottom.' One of the participants provided another word, 'down', with the intent of helping his interactant. This group was a trio, being that Anthony and Henry were together, using the same mobile phone, while Cesar, who has a turn in Excerpt 2, was spatially away. 
Table 1. Excerpt 1 - Anthony, Cesar, and Henry

\begin{tabular}{|c|c|c|c|c|c|}
\hline Line & Name & $\begin{array}{l}\text { Turn } \\
\text { Time }\end{array}$ & $\begin{array}{l}\text { Turn } \\
\text { Duration }\end{array}$ & Turn Talk & $\begin{array}{l}\text { Negotiated } \\
\text { Interaction }\end{array}$ \\
\hline 2 & Henry & $8: 47$ & $11 \mathrm{~s}$ & $\begin{array}{l}\text { ((Lines } 2 \text { - } 9 \text { were recorded in the same audio } \\
\text { file) })\end{array}$ & Yes \\
\hline & & & & there are flowers $(\ldots)$ in $(\ldots)$, & \\
\hline 3 & Anthony & - & - & there are flowers in the bottom (.) & Yes \\
\hline 4 & Henry & - & - & $=$ bottom $?=$ & Yes \\
\hline 5 & Anthony & - & - & $=$ in the bottom.$=$ & Yes \\
\hline 6 & Henry & - & - & $=$ bottom, yeah.$=$ & Yes \\
\hline 7 & Henry & - & - & is the right, bottom . & Yes \\
\hline 8 & Anthony & - & - & in the right bottom (.) bottom is down . & Yes \\
\hline 9 & Henry & - & - & down . you know, Cesar. & Yes \\
\hline
\end{tabular}

In Excerpt 1, Henry and Anthony were recording their turns using the same mobile phone. That is why there is only one turn time on the table, at 8:47, with a long duration of 11 seconds. The participants were recording their initial messages to Cesar, their partner who was in another location. At first, they chose to talk about the existence of flowers and their respective location in the image.

Excerpt 1 also shows that this was the beginning of the interaction, since we provided here lines 2 to 9 , which represent each of their turns. Additionally, Excerpt 1 shows that all their turns were considered as negotiated interaction because all the topics mentioned in each turn were addressed or attended to by the interactants. Nonetheless, negotiated interaction in these terms differ from assumptions held in SLA since it entails that interactants negotiate meaning even when communication follows a smooth flow, that means, without breakdowns, necessarily.

Regarding Excerpt 1, in Varonis and Gass' model (1985), the word 'bottom' could be considered the Trigger and the word 'down' was part of the Resolution phase. 'Down' was the Response to the Trigger. Although there was no Reaction to the response by Cesar in the Resolution phase, it seemed that participants understood each other regarding the position of the flowers in their images: they were not at the top; they were at the bottom of the images. Cesar got right the number of differences identified by considering the flowers comments by his peers. Later, Anthony added comments on the flowers that he could see in his image and Cesar acknowledges that by referring to the total number of differences identified so far:

Table 2. Excerpt 2 - Anthony, Cesar, and Henry

\begin{tabular}{llllll}
\hline Line & Name & $\begin{array}{l}\text { Turn } \\
\text { Time }\end{array}$ & $\begin{array}{l}\text { Turn } \\
\text { Duration }\end{array}$ & Turn Talk & $\begin{array}{l}\text { Negotiated } \\
\text { Interaction }\end{array}$ \\
\hline 39 & Anthony & - & - & $\begin{array}{l}\text { = there is orange flowers . the flowers are } \\
\text { orange , blue and pink with a little of white . } \\
\text { there are five differences . }\end{array}$ & Yes \\
41 & Cesar & $9: 06$ & $2 \mathrm{~s}$ & Yes \\
\hline
\end{tabular}

Although it took a long time, from lines 2-9 to lines 39 and 41, the participants' utterances allow for the interpretation that they were in agreement and understood each other concerning the flowers displayed in each image. Cesar seemed to agree with that by stating the number of differences that they had identified so far, in Excerpt 2, line 41. Therefore, this was an important characteristic analyzed: participants continued talking about other topics to try and reach agreement in the differences identified. 
Another common characteristic, which can be seen in Excerpt 3, from the pair Daniel and Vivian, was that, in case participants did not know one word and explicitly stated it to their partners, as a clarification request (Foster \& Ohta, 2005), their interactant simply repeated the sentence which contained the Trigger. In Excerpt 3, Vivian declared that she did not understand something, possibly referring to the word 'building.'

Table 3. Excerpt 3 - Daniel and Vivian

\begin{tabular}{|c|c|c|c|c|c|}
\hline Line & Name & $\begin{array}{l}\text { Turn } \\
\text { Time }\end{array}$ & $\begin{array}{l}\text { Turn } \\
\text { Duration }\end{array}$ & Turn Talk & $\begin{array}{l}\text { Negotiated } \\
\text { Interaction }\end{array}$ \\
\hline 19 & Vivian & $8: 54$ & $1 \mathrm{~s}$ & $\begin{array}{l}\text { I don't understand. } \\
\text { Q: there is a yellow building. (Line 17) }\end{array}$ & Yes \\
\hline 23 & Daniel & $8: 56$ & $4 \mathrm{~s}$ & $\begin{array}{l}\text { there is a yellow building in my image. } \\
\text { Q: I don't understand. ((Line 19) }\end{array}$ & Yes \\
\hline 25 & Vivian & $8: 58$ & $2 \mathrm{~s}$ & $\begin{array}{l}\text { in my image too. } \\
\text { Q: there is a yellow building in my image. (Line } \\
\text { 23) }\end{array}$ & Yes \\
\hline
\end{tabular}

Although the participant stated a clarification request, it was possible to notice that there was no elaboration on the term that caused the Trigger. Participants did not provide synonyms for the word 'building'; Vivian simply incorporated the term in another sentence later on. It was possible that she did some research on the term, either with peers who were close to her or on the internet. There was no textual or voice evidence that participants solved the nonunderstanding in the chat. Nonetheless, it seemed that the communication breakdown was solved by the agreement provided in line 25. Another possibility would be that Vivian might have remembered the word 'building', even by the color mentioned or by her interactant's utterance.

In Excerpt 4, one participant stated a clarification request by asking for repetition, which also characterizes an attempt to negotiate meaning in the interactional situation. They were talking about a possible backpack in their images, but as the terms used did not match, 'bag', 'schoolbag' and 'bagpack', Ramon decided to say that he did not understand and then he asked for repetition.

Table 4. Excerpt 4 - Erick, Louis, and Ramon

\begin{tabular}{llllll}
\hline Line & Name & $\begin{array}{l}\text { Turn } \\
\text { Time }\end{array}$ & $\begin{array}{l}\text { Turn } \\
\text { Duration }\end{array}$ & Turn Talk & $\begin{array}{l}\text { Negotiated } \\
\text { Interaction }\end{array}$ \\
\hline 16 & Ramon & $9: 04$ & $2 \mathrm{~s}$ & there is a schoolbag ? & Yes \\
17 & Erick & $9: 05$ & $2 \mathrm{~s}$ & there are two purple bags . & Yes \\
18 & Louis & $9: 05$ & $4 \mathrm{~s}$ & $\begin{array}{l}\text { there are two purple bagpack . } \\
\text { I don't/don't understand and repeat please . }\end{array}$ & Yes \\
21 & Ramon & $9: 07$ & $2 \mathrm{~s}$ & $\begin{array}{l}\text { Q: there are two purple bags . ((Line 17)) } \\
\text { there are a schoolbag in your image ? }\end{array}$ & Yes \\
33 & Ramon & $9: 13$ & $5 \mathrm{~s}$ & one difference is the bagpack. & Yes \\
\hline
\end{tabular}

Actually, there is one backpack in Picture A and two in Picture B. Another difference is the color: in Picture A, it is black and in Picture B they are purple. Excerpt 4 showed that participants were able to identify one difference referring 
to the backpacks. Ramon possibly associated the message 'There are two purple bags' with the fact that he identified one in the picture that he was holding and he defined it as a difference in the activity proposed.

Ramon also used the quotation feature on WhatsApp, line 21. Thus, it was possible to associate his repetition request directly to the part of the conversation that he did not get it clearly, 'There are two purple bags.' This allowed the interpretation that Ramon was trying to negotiate meaning with his peers. It might have been his intent to make sure that he got his messages across as well as understood his interactants' attempts to describe the image they had in hands.

On the one hand, the excerpts analyzed exemplified negotiation of meaning episodes in the online interaction that resembles the long-claimed propositions stated in the SLA area. On the other hand, the excerpts also initiated the discussion on negotiated interaction proposed in this study, which represents a possible expansion of SLA views on the topic. It adds the claim that interaction may take place through meaning exchange without necessarily involving language breakdowns or mis- and non-understandings.

This section also brought examples of interaction in which participants tried to support their peers in the understanding of the information, building upon the ideas that they were trying to convey by providing synonyms. The next sections address Split negotiation routines (Smith, 2003), Quoted turns, Written turns and Broken negotiation routines. All of them were interpreted as indicating movements towards maintaining the flow of the interaction besides facing possible non-understandings, comprehension breakdowns or limitations in terms of language resources.

\subsubsection{Split Negotiation Routines}

In Smith's (2003) terms, Split negotiation routines consist of a delay, sometimes a long delay, between the initial Trigger and the Indicator. Based on that, this study considers that Split negotiation routines are events of negotiation of meaning in which interactants continue the flow of conversation, even when they identify a Trigger and then return to that when they find convenient or at their own pace. However, in this study, many times participants did not identify any Triggers; our data showed that they simply decided to go back and comment on certain aspects or items mentioned during the online interaction. Consequently, we took the initial concept coined by Smith (2003) and expanded it to state that negotiated interaction may take place not following predetermined phases presented in the model by Varonis and Gass (1985) and updates added by Smith (2003).

Split negotiation routines were the most common characteristic found in this study, possibly either due to the affordances of the app WhatsApp and/or because participants found it appropriate to return to certain parts of the interaction at their own pace and will. Thus, this section examines instances of Split negotiation routines, besides showing their possible reason for frequent occurrence.

All the dyads and triads in this study had Split negotiation routines during their interactions. Participants presenting a Trigger, continuing talking about other subjects, and later on responding or commenting on certain facts that their peers had mentioned earlier in the online oral interaction were a recurrent characteristic.

In Excerpt 5, Bill talked about the number of dogs that he saw in his image. He went on describing other factors, such as information about some flowers and a lake. After Bill took four turns in a row, Josh responded to Bill about the dogs.

Table 5. Excerpt 5 - Bill and Josh

\begin{tabular}{|c|c|c|c|c|c|}
\hline Line & Name & $\begin{array}{l}\text { Turn } \\
\text { Time }\end{array}$ & $\begin{array}{l}\text { Turn } \\
\text { Duration }\end{array}$ & Turn Talk & $\begin{array}{l}\text { Negotiated } \\
\text { Interaction }\end{array}$ \\
\hline 8 & Bill & $9: 11$ & $3 \mathrm{~s}$ & there is a three dogs in image. & Yes \\
\hline 9 & Bill & $9: 11$ & $5 \mathrm{~s}$ & $\begin{array}{l}\text { there is a purple flowers on the a left pink } \\
\text { flowers. }\end{array}$ & Yes \\
\hline 10 & Bill & $9: 12$ & $3 \mathrm{~s}$ & there is a lake on the right image/image. & Yes \\
\hline 11 & Bill & $9: 12$ & $5 \mathrm{~s}$ & orange flowers on purple flowers . & Yes \\
\hline 12 & Josh & $9: 14$ & $5 s$ & there are two dogs in front (.) the house . & Yes \\
\hline
\end{tabular}


According to Smith (2003), this example fits the negotiated interaction phase proposed to describe an event that had not been presented in Varonis and Gass' model (1985). Many times, interactants continue the flow of the conversation and maybe just after a while or after other subjects came up is that they find the time or the opportunity to give or get a response to what they had said. For Smith, the Triggers were addressed with an Indicator later on in the Split negotiation routines. However, this study found that some Triggers were never attended to, thus naming them as Broken negotiation routines, explained later in this section.

The affordances of the application WhatsApp also allow for Split negotiation routines. Actually, they may even encourage that because the interaction promoted can be considered semi-synchronous, that is, interactants may take some time to answer all or some of the messages. Thus, participants recorded their phrases containing descriptions of the images and waited as long as they needed or wanted to respond to particular utterances, or even to have feedback on the aspects described to their peers. The following excerpt, for example, presented 19 turns before the response happened:

Table 6. Excerpt 6 - Anthony, Cesar, and Henry

\begin{tabular}{|c|c|c|c|c|c|}
\hline Line & Name & $\begin{array}{l}\text { Turn } \\
\text { Time }\end{array}$ & $\begin{array}{l}\text { Turn } \\
\text { Duration }\end{array}$ & Turn Talk & $\begin{array}{l}\text { Negotiated } \\
\text { Interaction }\end{array}$ \\
\hline 15 & Anthony & $8: 48$ & $3 \mathrm{~s}$ & there is a lake in the left of the picture. & Yes \\
\hline 34 & Cesar & $8: 59$ & $4 \mathrm{~s}$ & there is a lake in the right of my picture. & Yes \\
\hline 35 & Henry & 9:00 & $3 \mathrm{~s}$ & ok . two differences. & Yes \\
\hline 36 & Cesar & 9:02 & $7 \mathrm{~s}$ & $\begin{array}{l}\text { there is a lake in the right and a: yellow building } \\
\text { ahhh in the left of the picture. }\end{array}$ & Yes \\
\hline 37 & $\begin{array}{l}\text { Henry } \\
\text { and Anthony }\end{array}$ & 9:03 & $3 \mathrm{~s}$ & ok . four differences. ((they speak at the same time $))$ & Yes \\
\hline
\end{tabular}

Anthony mentioned that there was a lake on the left of his image. After 19 turns (from line 15 to 34), Cesar stated an utterance related to a lake in his image and Henry confirmed that it was another difference identified by the trio, in this case. Even after a long delay, participants were interacting and negotiating meaning throughout their interaction. Since the app or the activity allowed for later response, participants decided, perhaps even involuntarily, to describe as much as they could and after attending to certain parts of the interaction at their preferred pace and time. Nonetheless, in all the scripts among the different pairs and trios, there were turns in sequence, that is, turns in which the Responses were provided right after Triggers, in an uninterrupted manner. In addition, there were turns in which the Split negotiation routines were separated by only one utterance.

Split negotiation routines were a typical characteristic of online oral interaction identified in this study. This study attributed a different aspect to the concept coined by Smith (2003). Originally, Split negotiation routines referred to language breakdowns specifically. In this study, it alluded to negotiated interaction that could be represented by terms that interactants fully understood, but that were attended to in a split manner. Although they may seem disruptive, it is also possible that they may accelerate the continuation of the interaction since participants have access to all the messages received at a continuous pace.

Additionally, they might be seen as positive for beginners in the sense that they may provide the feeling of fluidness that is common in interactions in F2F or among fluent and/or NSs. The conversation was continued, meaning that the participants went on talking about other topics instead of just waiting for the other to respond to something specific that he/she said. In fact, they were continuing with their descriptions of the images that they had in hands. When they found fit, they picked the information that they wanted to respond to at that time.

\subsubsection{Quoted Turns}

Quoted turns were also a prevailing characteristic in this study. They consisted of turns connected to each other in a way that interactants could select specific messages and quote them right above their current message. On WhatsApp, it is also possible to select the desired message to address and after start typing your own. It automatically quotes the 
pre-selected message of your choice. It is possible to do that for one message at a time, instead of multiple messages concomitantly. In fact, Quoted turns are a feature of the app WhatsApp that may be used to respond and turn to specific messages when you record or write your response. It is also possible to quote messages connected to different modes of multimodal communication (textual, visual, \& aural). Interestingly, Quoted messages were commonly used with Split negotiation routines.

In this study, many Quoted turns consisted of Written turns ( $\mathrm{n}=29$ out of 54) and others were responded with audio $(n=25$ out of 54). Another fact noticed was that most of their uses referred to confirmation of differences identified in their peers' descriptions. Excerpt 7 exemplifies that:

Table 7. Excerpt 7 - Sam and Bernard

\begin{tabular}{|c|c|c|c|c|c|}
\hline Line & Name & Turn Time & Turn Duration & Turn Talk & $\begin{array}{l}\text { Negotiated } \\
\text { Interaction }\end{array}$ \\
\hline 1 & Sam & $8: 52$ & $2 \mathrm{~s}$ & there are people sittings . & Yes \\
\hline 2 & Sam & $8: 52$ & $4 s$ & $>$ there are trees.$<$ & No \\
\hline 3 & Bernard & $8: 58$ & $3 \mathrm{~s}$ & four persons sitting in a white table. & Yes \\
\hline 4 & Sam & $8: 59$ & $3 \mathrm{~s}$ & there is one people standing . & Yes \\
\hline 5 & Bernard & $8: 59$ & $2 \mathrm{~s}$ & there are three dogs . & Yes \\
\hline \multirow[t]{2}{*}{6} & Sam & $9: 02$ & WRITTEN & OK! & Yes \\
\hline & & & & $\begin{array}{l}\text { Q: four persons sitting in a white table. } \\
\text { ((Line 3)) }\end{array}$ & \\
\hline 7 & Sam & 9:04 & $2 \mathrm{~s}$ & there are no three dogs. & Yes \\
\hline 8 & Sam & 9:04 & $2 \mathrm{~s}$ & there are two dogs. & Yes \\
\hline 9 & Bernard & 9:05 & $2 \mathrm{~s}$ & there are three dogs . & Yes \\
\hline \multirow[t]{2}{*}{10} & Sam & 9:07 & WRITTEN & There aren't three dogs & Yes \\
\hline & & & & Q: there are three dogs . ((Line 9)) & \\
\hline
\end{tabular}

The Quoted turns were represented with a $\mathbf{Q}$, from Quoted, in boldface. To illustrate, in Excerpt 7, Sam was trying to convey a message about the people and the dogs in his image. In relation to the people, Bernard responded and specified it by adding the exact number of people and the fact that there was a table. Concerning the dogs, Sam stated and quoted Bernard's message to claim that in his image there were two dogs only, different from Bernard's in which there were 3 dogs. Sam selected the specific messages that he wanted to respond to and quoted them, possibly to make sure that Bernard would get the information right. It was possible to notice that the Quoted turns helped the flow of the conversation by making clearer which message exactly Sam wanted to respond to, especially when dealing with Split negotiation routines.

\subsubsection{Written Turns}

Most participants resorted to written messages in their interaction; from 15 pairs or trios engaged in the WhatsApp activity, only one trio and two pairs did not write any messages; these preferred to use only the audio-recorded interaction. When participants received the instructions for the activity, they were encouraged to communicate with each other by speaking. However, they were also instructed that they could resort to multimodal communication (textual, visual, \& aural) in the form of emoticons, images, GIFs, etc., as they wished. They were free to choose, as long as they interacted orally for the most part of the time, since they were taking part in a speaking activity.

As a consequence, most of the interaction in each dyad or triad was orally through audio-recorded messages, although in most of the groups there was also written messages $(n=57)$ in a fewer number if compared to the audio-recorded 
ones $(n=422)$. Most of the written turns concentrated on the identification of the differences found correlating the images. Participants were directly addressing the distinctions as in the following excerpt:

Table 8. Excerpt 8 - Daniel and Vivian

\begin{tabular}{llllll}
\hline Line & Name & Turn Time & Turn Duration & Turn Talk & $\begin{array}{l}\text { Negotiated } \\
\text { Interaction }\end{array}$ \\
\hline 42 & Daniel & $9: 06$ & WRITTEN & 5 differences? & Yes \\
43 & Vivian & $9: 06$ & WRITTEN & I think is 4. & Yes \\
\hline
\end{tabular}

Participants showed attention to the accountability of the divergences that they were identifying in their images. Since it was explained for them that this was the main objective of the activity itself, they focused on pointing them out explicitly in the interactional groups on WhatsApp. In addition, they might have cared for the use of Written turns mostly for the accountability of the dissimilarities identified in their images because they intended to keep the interactional moves organized to meet the activity's main objective.

The Written turns represented another type of resource used by the participants to negotiate meaning in the sense proposed in this study. By writing some of their messages, participants demonstrated that they were making an effort to organize their findings in terms of differences identified in the images. These turns may have supported the participants' exchange of meaning by allowing time and language resources to other aspects of the interaction.

\subsubsection{Broken Negotiation Routines}

The Broken negotiation routines were a category of analysis developed for this study since they represented one of the main aspects identified. Many times, participants initiated a negotiation with their peers, but they never got a reply. That defines a Broken negotiation routine, which is a turn that has not been answered or addressed to by the interactants. They were a significant characteristic in this study since it was found in many of the interactional groups $(\mathrm{n}=10$ out of 15$)$. The analysis considered the Broken negotiation routines as non-negotiated interaction, signaling them with the word 'No' in the Negotiated interaction column in the tables. Excerpt 9 brings an example of a Broken negotiation routine:

Table 9. Excerpt 9 - Luke and Marian

\begin{tabular}{|c|c|c|c|c|c|}
\hline Line & Name & $\begin{array}{l}\text { Turn } \\
\text { Time }\end{array}$ & Turn Duration & Turn Talk & $\begin{array}{l}\text { Negotiated } \\
\text { Interaction }\end{array}$ \\
\hline 13 & Marian & $8: 58$ & $5 \mathrm{~s}$ & there is one building (..) on the left & No \\
\hline 14 & Marian & 8:59 & $7 \mathrm{~s}$ & in my image (..) ahhh there are three dogs & Yes \\
\hline 15 & Marian & 8:59 & $5 \mathrm{~s}$ & there is a lake (.) on the right in image . & Yes \\
\hline 16 & Luke & 9:00 & $2 \mathrm{~s}$ & in my image there are two dogs & Yes \\
\hline 17 & Luke & 9:00 & $8 \mathrm{~s}$ & $\begin{array}{l}\text { in my image ahhh there is a lake on the left, } \\
\text { no on the right. }\end{array}$ & Yes \\
\hline 18 & Marian & 9:01 & $9 \mathrm{~s}$ & $\begin{array}{l}\text { there is a yellow building on the left @@@ } \\
\text { on the left. }\end{array}$ & No \\
\hline
\end{tabular}

In Excerpt 9, Marian referred to a building on the left of her image. She went on and included information about some dogs and a lake. When Luke responded, he concentrated on part of the facts provided by Marian, leaving behind the building on the left. He never actually referred to that throughout the whole interaction with Marian. 
Among the possible interpretations about Broken negotiation routines, it could be the case that the time limit of 30 minutes affected it. In this way, participants could possibly be rushing to attend to most information, leaving behind some of their interactants comments. Another potential reason could be that the participants did not know the vocabulary being used and, thus, decided to ignore it. Additionally, it is also possible to say that participants did not find that those utterances represented relevant aspects to be commented. Hence, there would be many potential explanations to justify Broken negotiation routines, such as time limit, irrelevance, non-visualization, forgetfulness, disregard, etc.

Broken negotiation routines were also, in a way, described in other studies, although not under this name. Smith (2003) and Jungmi (2003) identified in their research a lack of continuity or interactants ignoring some messages uttered, yet they simply elaborated that the interaction did not present all the phases proposed in the model by Varonis and Gass (1985). The authors observed that the interaction could simply not have all the phases initially proposed. Notwithstanding, if it is a recurrent characteristic, as in our study, it is definitely necessary to address that with a proper name, assigning it to a different category. Moreover, it is essential to describe and understand all the characteristics that stood out from online interaction to be able to assemble features that may influence positively on language pedagogy.

\section{Discussion}

\subsection{Adding a Discussion on Interaction in SLA}

This section deals with a discussion on the findings of this investigation. The main inquiries in the research questions were:

(a) to study characteristics of online oral audio-recorded negotiated interaction among beginner learners of English, considering the affordances of WhatsApp;

(b) to analyse how the affordances of the app WhatsApp played a role in the negotiated interaction characteristics of beginner learners of English, considering existing negotiation of meaning models; and,

(c) to identify and analyse which communication resources - multimodal (textual, visual, \& aural) - were used by the participants to assist their oral interaction online on WhatsApp, by focusing on how they may have interplayed with the interaction.

Since the inquiry of each research question is related to the others, the discussion brings an altogether commentary by trying to explain the main findings, which also cover for the topics of investigation in this study. Firstly, considering the interaction characteristics presented, the foremost relevant characteristic of online oral interaction was that negotiated interaction may happen throughout interactional moves that are not necessarily represented by language breakdowns. In fact, the data in this study showed that online oral interaction among beginners might not follow strictly the patterns presented in existent models (Jungmi, 2003; Smith, 2003; Varonis \& Gass, 1985) that describe negotiation of meaning for language learning in SLA. What the results specifically of this research differ from the descriptions models and existing phases proposed was that negotiation of meaning might also have happened when learners understood each other.

That is to say, in SLA, negotiation of meaning relies on language problems, such as non-understandings, lack of knowledge, mispronunciation, and/or language breakdowns (Bower \& Kawaguchi, 2011; Ellis, 1999; Foster \& Ohta, 1995; Gass \& Selinker, 1994; Long, 1996; Mackey et al., 2000). However, the data in this study showed that negotiation of meaning happens throughout the interaction in which there are not necessarily language breakdowns. Essentially, it pointed to the possibility that beginners might have negotiated meaning when they were able to get their messages across and make sense in the context of their interaction, without following strictly the phases proposed in the models by Varonis and Gass (1985), Jungmi (2003), and Smith (2003).

Secondly, concerning the other main characteristics identified, the results showed that Split negotiation routines (Smith, 2003) may have resulted from the affordances of WhatsApp. Since the app allows the recording of multiple messages, users may not record the whole message at once. They may record it in parts, especially if they are trying to interact synchronously with their interlocutors, which was the case in this study. Thus, hearers may decide to record all their messages at once and end up responding to Triggers when they take time to listen to their interlocutors' recorded messages, at one's own pace and time. In addition, this may happen because WhatsApp recorded messages 
allow for interaction that can be characterized as semi-synchronous since speakers and hearers can decide to record and listen consecutively or sometime later.

Thirdly, the Broken negotiation routines may have resulted from the same reason as the Split negotiation routines. The affordances of the app WhatsApp allow users to write or record multiple messages at a time. Hence, for this study, it is possible that some topics addressed by the participants got lost among other messages. Moreover, it is also a possible interpretation that some participants decided that it was not relevant to address some topics commented by their interactants.

Fourthly, the Quoted turns were another aspect that may have resulted from the affordances of the app. Since WhatsApp has a feature that enables its users to select specific messages and respond to them directly by showing them as a quotation, it is possible that our participants decided to quote some of their turns. In this analysis, it was emphasized that the Quoted turns meant an organizational resource for our participants to state their comments of the aspects that they were identifying in the images received. By selecting specific messages to address, participants were deciding on certain information to respond to or comment. This means that they were able to understand, or at least they were trying to understand, the messages that they were addressing. Besides that, they were devoting time to comprehend the aspects that they selected to talk about. Certainly, this may have affected positively the negotiation of meaning in the online interactions, in the sense of keeping the flow of the conversation.

The Written turns can also be interpreted in the light of the affordances of the app. In fact, they can be linked and explained along with the Quoted turns, since it is possible to select a message and to quote it with an audio or written response. In this study, many Quoted turns consisted of Written turns ( $n=29$ out of 54) and others were responded to with audio ( $n=25$ out of 54). Additionally, it was noticed that most of the Written turns were used to refer to the confirmation of differences identified by the participants in their descriptions.

Similarly to the Quoted turns, the use of the Written turns were interpreted as an effort from the participants to negotiate meaning. Since they were mostly used to confirm the number of differences found in their spot-thedifference online activity, it is possible that participants were trying to make sure that they registered their answers and checked them up with their peers in the WhatsApp group, not only by speaking but also in writing. Indeed, most of the participants only resorted to Written turns, instead of other modes of multimodal interaction, such as the use of images, emoticons, web links, videos, pictures, GIFs, among others. In effect, learners resorted to written interaction most of the time to account for the differences found between Picture A and B. Many times, the Written turns were quoting others as a response. However, this characteristic has not been seen as defining the interactional characteristics in the study. Instead, it was interpreted as a way of organizing the negotiation of meaning and making clear the spotting of the differences found in each image.

\section{Conclusion}

This study analyzed characteristics of online oral interaction among beginner learners of English with the app WhatsApp. For that reason, the analysis considered previous theories and models for interaction in language learning. Results pointed to similarities and differences from what has been proposed in terms of the Interaction Hypothesis and models for Negotiation of Meaning. Briefly put, the Interaction Hypothesis and the model for Negotiation of Meaning, along with its updates, state that learners profit from negotiation of meaning during interaction, which entails language problems, such as language breakdowns and non-understandings. Interactants may profit from that during interaction in order to build up on the language problems, by correcting them and learning or noticing new facts about the target language. In fact, this study adds to that, even sustaining the arguments for negotiation of meaning during interaction. This investigation showed Triggers and Resolution phases in the data as well as Split negotiation routines and the Pop phases. However, this study also showed that there might be more to that than what has been described so far in the SLA area, according to theories and research published so far, to the best of our knowledge.

\subsection{Implications of the Study}

Taking into consideration that in SLA negotiation of meaning entails language breakdowns, this investigation claims that learners may profit as well from interaction in case there are language understandings, as opposed to language breakdowns. In fact, regular fluid interaction may also be negotiated and might be effective for language development just as much as the negotiated interaction. Particularly, in this study participants were beginner learners, who usually have limited language resources to interact orally (e.g. vocabulary, syntax, pronunciation, intonation, fluency, and accuracy). 
This study argues that negotiated interaction consists of exchanging meanings and getting messages across, without necessarily facing and dealing with language breakdowns from time to time. Based on this study's findings, the models analyzed still well represent phases of negotiation of meaning. However, this study points to an extension of the concept of the term, which was centrally grounded on language non-understandings. In effect, negotiated interaction in SLA referred to language breakdowns, non-understandings, and solving language problems. However, by the analysis of online interaction among beginner learners of English, this study showed that negotiated interaction may happen while interactants are exchanging meanings without interruptions to solve what they did not understand. There are other ways that interactants can solve non-understandings nowadays, while interacting online. They no longer have to push down the flow of the interaction to get to know a word and its meaning, for example. They can maintain the interaction, look up a word online on a dictionary, and keep exchanging meanings.

In many SLA long-held theories, hypotheses, and studies analyzed for the development of our research, interaction meant communicating face-to-face, mainly having native speakers with learners of a second, sometimes a foreign language. With the technological affordances that we have available nowadays, there are different aspects in the sense of interaction, such as web conferencing resources and audio-recorded messages on WhatsApp, which were part of the data analyzed in this study. Hence, all the different scenarios and resources may play a role in how we describe, understand, and interpret negotiated interaction. In this line of thought, this study may add to the understanding of negotiated interaction for language learning by showing that there are specificities that need acknowledgment according to the context in which interaction takes place.

\section{References}

Amry, A. B. (2014). The impact of Whatsapp mobile social learning on the achievement and attitudes of female students compared with face-to-face learning in the classroom. European Scientific Journal, 10(22), 116-136. Retrieved from: https://eujournal.org/index.php/esj/article/viewFile/3909/3700

Aragão, R. (2017). Emoções e ações de professores ao falar inglês no WhatsApp. Revista Brasileira de Linguística Aplicada, 17(1), 83-112. Retrieved from: http://www.scielo.br/pdf/rbla/v17n1/1984-6398-rbla-17-0100083.pdf https://www.sciencedirect.com/science/article/pii/S0346251X11000893

Aragão, R., \& Lemos, L. (2017). WhatsApp e multiletramentos na aprendizagem de inglês no Ensino Médio. Polifonia, 24(1), 73-94. Retrieved from: http://periodicoscientificos.ufmt.br/ojs/index.php/polifonia/article/view/6034.

Blake, R. (2005). Bimodal CMC: The glue of language learning at a distance. CALICO Journal, $22(3), 497-511$. Retrieved from: https://www.jstor.org/stable/24147935

Blake, R. (2008). Brave new digital classroom: Technology and foreign language learning. Washington, D.C.: Georgetown University Press.

Bouhnik, D., \& Deshen, M. (2014). Whatsapp goes to school: Mobile instant messaging between teachers and students. Journal of Information Technology Education Research, 13, 217-231. Retrieved from: http://www.jite.org/documents/Vol13/JITEv13ResearchP217-231Bouhnik0601.pdf

Bower, J., \& Kawaguchi, S. (2011). Negotiation of meaning and corrective feedback in Japanese/English eTandem. Language Learning \& Technology, 15(1), 41-71. Retrieved from: https://eric.ed.gov/?id=EJ946175

Castrillo, M. D., Martín-Monje, E., \& Bárcena, E. (2014). Mobile-based chatting for meaning negotiation in foreign language learning. 10 International Conference Mobile Learning, 2014, 49-58. Retrieved from: https://files.eric.ed.gov/fulltext/ED557212.pdf

Castrillo, M. D., Martín-Monje, E., \& Bárcena, E. (2015). New forms of negotiating meaning on the move: The use of mobile-based chatting for foreign language distance learning. IADIS International Journal, 2(2), 51-67. Retrieved from: http://www.iadisportal.org/ijwi/papers/2014121204.pdf

Chapelle, C. A. (2003). English language learning and technology. Amsterdam: John Benjamins.

Cohen, L., Manion, L., \& Morrison, K. (2011). Research methods in education. Routledge, London.

Compernolle, R. A. van. (2015). Interaction and second language development: A Vygotskian perspective. Amsterdam: John Benjamins. 
Cunha, A. G. (2016). Coaching instrucional. Formação Continuada em Ensino de Línguas. São Paulo: Parábola Editorial.

Dörnyei, Z. (2011). Research methods in applied linguistics: Quantitative, qualitative and mixed methodologies. UK: Oxford University Press.

Ellis, R. (1991). The interaction hypothesis: A critical evaluation. Article presented at Regional Language Centre Seminar. Singapore: April 22-28th. Retrieved from: https://eric.ed.gov/?id=ED338037

Ellis, R. (1999). Learning a second language through interaction. Amsterdam: John Benjamins.

Fernández-García, M., \& Martínez-Arbelaiz, A. (2002). Negotiation of meaning in nonnative speaker-nonnative speaker synchronous discussions. CALICO Journal, 19(2), 279-294.

Firestone, W. A. (1987). Meaning in method: The rhetoric of quantitative and qualitative research. Educational Researcher, 16(7), 16-21. Retrieved from: https://journals.sagepub.com/doi/10.3102/0013189X016007016

Fonte, R., \& Caiado, R. (2014). Práticas discursivas multimodais no WhatsApp: uma análise verbo-visual. Desenredo, Passo Fundo, 10(2), 475-487. Retrieved from http://seer.upf.br/index.php/rd/article/view/4147

Foster, P., \& Ohta, A. S. (2005). Negotiation for meaning and peer assistance in second language classrooms. Applied Linguistics, 26(3), 402-430. Retrieved from: https://academic.oup.com/applij/articleabstract/26/3/402/181415?redirectedFrom=fulltext

Gass, S., \& Selinker, L. (1994). Second language acquisition: An introductory course. Mahwah, NJ: Lawrence Erlbaum Associates.

Griffee, D. T. (2012). An introduction to second language research methods: Design and data. United States of America, Library of Congress Cataloging-in-Publication Data.

Guo, S. (2013). Applying Web-conferencing in a Beginners' Chinese Class. 30th ascilite Conference 2013 Proceedings, 345-349. Retrieved from: https://www.learntechlib.org/p/171148/

Hatch, E. M. (1978). Discourse analysis and second language acquisition. In E. M. Hatch. (1978), Second language acquisition: A book of readings. Rowley: Newbury, 401-435.

Hampel, R., \& Stickler, U. (2012). The use of videoconferencing to support multimodal interaction in an online classroom. $\quad \operatorname{ReCALL}, \quad 24 \quad$ (2), $\quad 116-137 . \quad$ Retrieved from: https://oro.open.ac.uk/31046/1/Regine\%20Stickler\%20use\%20of\%20videoconferencing.pdf

Heins, B., Duensing, A., Stickler, U., \& Batstone, C. (2007). Spoken interaction in online and face-to-face language tutorials. Computer Assisted Language Learning, 20(3), 279-295.

Jepson, K. (2005). Conversations and negotiated interaction in text and voice chat rooms. Language Learning \& Technology, 9(3), 79-98. Retrieved from: https://eric.ed.gov/?id=EJ846346

Jones, L. C., Murphy, C. A., \& Holland, A. (2015). The more things change, the more they stay the same, or do they? Revisiting classroom interaction approaches and their effects on quantity and characteristics of language production. CALICO Journal, 32(2), 245-272. Retrieved from: https://www.jstor.org/stable/calicojournal.32.2.245?seq=1

Jungmi, K. (2003). A study of negotiation of meaning in NNS-NNS interactions -focusing on synchronous CMC. Paper presented at the 8th Conference of Pan-Pacific Association of Applied Linguistics. Japan. Retrieved from http://www.paaljapan.org/resources/proceedings/PAAL8/pdf/pdf019.pdf

Kaieski, N., Grings, J. A., \& Fetter, S. A. (2015). Um estudo sobre as possibilidades pedagógicas de utilização do WhatsApp. Revista Novas Tecnologias na Educação, Porto Alegre, 13, 1-10. Retrieved from: https://seer.ufrgs.br/index.php/renote/article/view/61411

Kenning, M. M. (2010). Differences that make the difference: A study of functionalities in synchronous CMC. ReCALL, 22(1), 3-19. doi: https://doi.org/10.1017/S0958344009990164 
Kern, R. (1995). Restructuring classroom interaction with networked computers: Effects on quantity and characteristics of language produced. The Modern Language Journal, 79(4), 457-476. doi: 10.2307/329999 https://www.jstor.org/stable/329999

Leite, N. C., \& Silva, M. O. (2015). WhatsApp: Caracterização do gênero chat em contexto de ensino de línguas estrangeiras. Texto Livre: Linguagem e Tecnologia, 8(1), 85-97. Retrieved from http://www.periodicos.letras.ufmg.br/index.php/textolivre/article/viewFile/7365/7696

Lima, D. C. (Org.). (2009). Ensino e Aprendizagem de Lingua Inglesa. São Paulo: Parábola Editorial.

Lima, D. C. (Org.). (2014). Inglês em escolas públicas não funciona? Uma questão, múltiplos olhares. São Paulo: Parábola Editorial.

Long, M. H. (1981). Input, interaction and second language acquisition. In Winitz, H. (ed.), Native language and foreign language acquisition. Annals of the New York academy of sciences, 379, 259-278. DOI: https://doi.org/10.1017/S0272263199004027

Long, M. H. (1996). The role of linguistic environment in second language acquisition. In W. Ritchie and T. K. Bhatia (Eds.), Handbook of second language acquisition (413-468). San Diego: Academic Press.

Mackey, A. (2007). Interaction as practice. In: Dekeyser, R. M. (Editor) Practice in a second language. Cambridge: Cambridge University Press, 85-137.

Mackey, A., Gass, S., \& McDonough, K. (2000). Do learners recognize implicit negative feedback as feedback? Studies in Second Language Acquisition, 22, 471-497. Retrieved from: http://www.eltsjournal.org/archive/value5\%20issue1/1-5-1-17.pdf

Matos, F. A. M. (2011). O Skype como ferramenta de interacção e colaboração no ensino e aprendizagem de línguas estrangeiras em teletandem (Unpublished Master's Dissertation). Universidade Aberta, Lisboa, Portugal. Retrieved from: https://pdfs.semanticscholar.org/9d14/0eca491939da3e1b507c7ead22a445c44d09.pdf

Menezes, V. L. (2010). Aprendendo Inglês no Ciberespaço. In Menezes, Vera Lúcia (Editor), Interação $e$ Aprendizagem em Ambiente Virtual. Minas Gerais: UFMG, 320-359.

Menezes, V. L. (2013). Interação e aquisição de segunda língua: Uma perspectiva ecológica. In Gerhardt, A.0 Amorim, M., Carvalho, Á. M. (Eds.) Linguística Aplicada e Ensino de Lingua e Literatura. Campinas: Pontes Editores, 187-205.

Menezes, V. L. (2018). Tecnologias digitais para o desenvolvimento de habilidades orais em inglês. D.E.L.T.A., 4(34), 1319-1351.

Miccoli, L., \& Cunha, A. G. (2016). Faça a Diferença. Ensinar Línguas Estrangeiras na Educação Básica. São Paulo: Parábola Editorial.

Nunan, D. (2008). Research methods in language learning. New York: Cambridge University Press.

Oliveira, L. A. (2014). Métodos de Ensino de Inglês. São Paulo: Parábola Editorial.

Oliveira, E. D. S., Oliveira, F. S., Medeiros, H., Leite, J. E. R., \& dos Anjos, E. G. (2014). Estratégias do uso do WhatsApp como um ambiente virtual de aprendizagem em um curso de formação de professores e tutores. In Simpósio Internacional de Educação a Distância. Universidade Federal de São Carlos. Retrieved from: http://sistemas3.sead.ufscar.br/ojs/index.php/2014/article/view/835

Parâmetros Curriculares Nacionais (PCNs). (2000). Linguagens, Códigos e suas Tecnologias. Língua Estrangeira Moderna. Ensino Médio. Brasília: MEC/SEF, p. 93-138.

Plana, M., Gimeno, A., Appel, C., \& Figueras, I. T. (2013). Improving learners' reading skills through instant short messages: a sample study using WhatsApp. Global perspectives on Computer-Assisted Language Learning (4 ed.) Glasgow: Scottish Exhibition Center in Glasgow, 80-84. DOI 10.5040/9781474248327.0027

Rambe, P., \& Bere, A. (2013). Using mobile instant messaging to leverage learner participation and transform pedagogy at South African University of Technology. British Journal of Educational Technology, 44(4), 544561. Retrieved from: https://scinapse.io/papers/1933057298 
Rodrigues, T. (2016). A utilização do aplicativo WhatsApp por professores em suas práticas pedagógicas. 6o Simpósio Hipertexto e Tecnologias na Educação e $2 o$ Colóquio Internacional de Educação com Tecnologias. Retrieved from $\quad$ http://www.nehte.com.br/simposio/anais/Anais-Hipertexto2015/A\%20utiliza\%C3\%A7\%C3\%A30\%20do\%20aplicativo.pdf

Salbego, N. N., \& Tumolo, C. H. S. (2018). Interação oral online para aprendizagem de línguas. Proceedings from CIET: $\quad$ EnPED, $\quad$ May $2018 . \quad$ Retrieved from http://cietenped.ufscar.br/submissao/index.php/2018/article/view/585

Schmidt, R. W. (1990). The role of consciousness in second language learning. Applied Linguistics, 11, 129-158. Retrieved from: https://nflrc.hawaii.edu/PDFs/SCHMIDT\%20The\%20role\%20of\%20consciousness\%20in\%20second\%201a nguage\%20learning.pdf

Senefonte, F. H. R., \& Talavera, M. N. G. (2018). O WhatsApp como ferramenta no ensino-aprendizagem de língua inglesa. Entretextos, Londrina, 8(1), 241-264. Retrieved from http://www.uel.br/revistas/uel/index.php/entretextos/article/view/33971/23839

Severo, S. S. (2017). O uso do WhatsApp como ferramenta para o desenvolvimento da habilidade comunicativa em inglês como língua estrangeira em um contexto de Blended Learning (Unpublished Master's Dissertation). Universidade do vale do Rio dos Sinos. Programa de Pós-Graduação em Linguística Aplicada. Retrieved from: http://www.repositorio.jesuita.org.br/handle/UNISINOS/6088

Shekary, M., \& Tahririan, M. H. (2006). Negotiation of meaning and noticing in text-based online chat. The Modern Language Journal, 90(iv), 557-573. doi: https://doi.org/10.1111/j.1540-4781.2006.00504.x

Smith, B. (2003). Computer-mediated negotiated interaction: An expanded model. The Modern Language Journal, 87(i), 38-57. Retrieved from: https://www.jstor.org/stable/1192998

Souza, C. F. (2015). Aprendizagem sem distância: tecnologia digital móvel no ensino de língua inglesa. Texto Livre: Linguagem e Tecnologia, Belo Horizonte, 8(1), 39-50. Retrieved from: http://www.periodicos.letras.ufmg.br/index.php/textolivre/article/view/6497

Stickler, U., Smith, B., \& Shi, L. (2016). Using eye-tracking technology to explore online learner interactions. In C. Caws; M. J. Hamel, Language-Learner Computer Interactions. Theory, Methodology and CALL Applications (163-186). USA: John Benjamins Publishing Company.

Strauss, A., \& Corbin, J. (1998). Basics of qualitative research: Techniques and procedures for developing grounded theory ( $2^{\text {nd }}$ ed.). Thousand Oaks, CA: Sage Publications, Inc.

Susilo, A. (2014). Exploring facebook and WhatsApp as supporting social network applications for English learning in higher education. Teaching and Learning in the 21st Century: Challenges for Lecturers and Teachers, Conference on Professional Development in Education (PDE2014). Widyatama University Indonesia, Open University Indonesia and Open University Malaysia. Repository Widyatama, 2014. Retrieved from http://repository.widyatama.ac.id/xmlui/handle/123456789/3317?show=full

Susilo, J. (2016). Pengembangan Kurikulum Bahasa Indonesia Bagi Penutur Asing. Jurnal Pendidikan Bahasa dan Sastra Indonesia, 3(1), 46.

Swain, M. (1985). Communicative competence: Some roles of comprehensible input and comprehensible output in its development. In S. M. Gass \& M. Madden (Eds.), Input in second language acquisition (235-253). Rowley: Newbury House.

Swain, M. (1995). Three functions of output in second language learning. In G. Cook \& B. Seidlhoffer (Eds.). Principle \& practice in applied linguistics (125-144). Oxford: Oxford University Press.

Tannenbaum, R. J., \& Wylie, E. C. (2015). Mapping the TOEIC tests in the CEFR. Educational Testing Service. United States and other countries. Retrieved from: https://www.ets.org/s/toeic/pdf/toeic-cefr-flyer.pdf

Thomas, M., Reinders, H., \& Warschaeur, M. (2014). Contemporary computer-assisted language learning. Bloomsbury, London, UK. 
Tudini, V. (2003). Using native speakers in chat. Language Learning \& Technology, 7(3), 141-159. Retrieved from: https://eric.ed.gov/?id=EJ674823

Varonis, E., \& Gass, S. (1985). Non-native/non-native conversations: A model for negotiation of meaning. Applied Linguistics, 6, 71-90. Retrieved from: https://academic.oup.com/applij/articleabstract/6/1/71/171724?redirectedFrom=fulltext

Verjano, A. C. (2013). Using Skype in a primary class: A case study. Bellaterra Journal of Teaching and Learning Language and Literature, 6(2), 49-68. doi: https://doi.org/10.5565/rev/jt13.521

Warschauer, M. (1996). Comparing face-to-face and electronic discussion in the second language classroom. CALICO Journal, 13(2), 7-26. doi: 10.1558/cj.v13i2-3.7-26

Yanguas, I. (2010). Oral computer mediated interaction between L2 learners: It's about time! Language Learning \& Technology, 14(3), 72-93. Retrieved from: https://eric.ed.gov/?id=EJ907768 